\title{
MEMBANGUN KARAKTER MAHASISWA MELALUI KEGIATAN ANALISIS SASTRA POPULER REMEMBER WHEN "KETIKA KAU DAN AKU JATUH CINTA" (KAJIAN MIMETIK) KARYA WINNA EFENDI
}

\author{
Oleh
}

Ira fatmawati

Universitas Trunojoyo Madura

\section{ABSTRAK}

Seiring dengan majunya zaman maka cara pengajaran karakter jugaharus bisa menyesuaikan dengan tingkat kemajuan pengetahuan dan jugateknologinya. Salah satu hal yang harus selalu terbentuk dengan baik yaitu karakter mahasiswa. Karakter dapat terbentuk melalui kebiasaan dan lingkungannya. Agar pengajaran karakter dapat terwujud maka harus menggunakan cara yang juga sedang populer di kalangan mahasiswa, yaitudengan membaca karya sastra populer. Karya sastra populer yang menjadi data penelitian ini yaitu novel yang berjudul Remember When " Ketika Kau dan aku Jatuh" karya Winna Efendi. Teori yang digunakan untuk menganalisis yaitu teori Sosiologi sastra (mimetik). Sedangkan metode penelitian yang digunakan yaitu kualitatif deskriptif. Tujuan penelitian yaitu untuk mendeskripsikan karakter tokoh yang dapat diadopsi dalam kehidupan mahasiswa setelah membaca novel populer tersebut. Hasil analisis karakter tokoh pada penelitian ini yaitu hendaknya para remaja dapat hidup sederhana, tidak membenci masyararakat miskin, tidak melalukan hubungan yang diluar batas, mudah memaafkan, rajin bclajar, mandiri, hidup sehat, dan dapat menyelesaikan masalah secara baik tanpa putus asa. Dari hasil penelitian ini diharapkan mahasiswa bisa memanfaatkan kegemaran dalam membaca novel populer untuk membangun kepribadiannya secara berkala. Karena pada dasarnya karya sastra adalah cerminan dari kehidupan yang dapat mengubah kebiasaan masyarakat dengan cara memunculkan beragam karakter dari tokohtokohnya. Pemilihan sastra populer sebagai sumber data ini dikarenakan bacaan tersebut memiliki jalan cerita yang sederhana dan bahasanya mudah dipahami.

Kata kunci: Karakter, sastra populer, mimetik

\section{PENDAHULUAN}

Karya sastra yang banyak beredar di masyarakat adalah karya sastra populer, karena ceritanya selalu mengikuti perkembangan zaman dan alurnya juga mudah untuk dipahami. Hal itulah yang membuat masyarakat gemar membaca cerita sastra populer. Tidak terkecuali mahasiswa, mereka lebih suka membaca karya sastra yang memiliki pilihan kata dan alur yang mudah untuk dipahami. Masyarakat selalu melakukan identifikasi perilaku dan karakter terhadap tokoh-tokoh yang ada dalam cerita tanpa ada perintah dan paksaan. Sedikit banyak apa yang dibaca akan memengaruhi cara berpikir atau perilaku seseorang. Oleh karena itu, media sastra populer sangat tepat bila digunakan untuk menanamkan karakter pada masyarakat terutama pada mahasiswa. Tujuan penelitian ini yaitu itu untuk mendeskripsikan cara membangun karakter mahasiswa melalui kegiatan analisis sastra populer remember when "ketika kau dan aku jatuh cinta" (kajian mimetik) karya Winna Efendi. Sedangkan dipilihnya novel tersebut karena novel tersebut memiliki tokoh utama yang memiliki karakter tidak bisa terutama pada penyelesaian konflikkonflik yang ada. Selain itu bahasa pada novel ini mudah dipahami karena menggunakan 
bahasa populer sehari-hari yang tidak asing bagi masyarakat. Sumber data pada penelitian ini yaitu novel remember when "ketika kau dan aku jatuh cinta" (kajian mimetik) karya Winna Efendi. Sedangkan data pada penelitian ini berupa kutipan-kutipan dari novel.

Teori sastra yang digunakan pada penelitian ini yaitu teori mimetik. Secara umum peendekatan mimetik adalah pendekatan yang mendasarkan pada hubungan karya sastra dengan universe (semesta) atau lingkungan sosial budaya yang melatarbelakangi lahirnya karya sastra itu. Dengan demikian dapat dinyatakan bahawa karya sastra pada hakikatnya adalah tanggapan seorang pengarang terhadap sitauasi di sekelilingnya.

Pandangan semacam ini berangkat dari pemikiran bahwa karya sastra (seni) merupakan refleksi dari kehidupan nyata. Refleksi ini terwujud karena adanya peniruan dan dipadukan dengan imajinasi pengarang terhadap realitas alam atau kehidupan manusia.

Berbicara mengenai pandangan mimetik terhadap karya sastra itu, pada dasarnya tidak dilepaskan dari pemikiran plato. Plato, dengan teori mimesisnya dianggap sebagai pelopor teori sosial sastra (Damono, 1979:16). Kata mimesis (bahasa Yunani) berarti tiruan. Teori mimesis menganggap karya sastra sebagai tiruanalam atau kehidupan (Abrams, 1981).Menurut pandangan Plato, segala yang ada di dunia ini sebenarnya hanya merupakan tiruan dari kenyataan tertinggi yang berada di dunia gagasan. Dalam dunia gagasan, ada gagasan mengenai manusia, semua manusia yang ada di dunia ini (manusia nyata) adalah tiruan dari manusia yang ada di dunia gagasan tersebut.

\section{METODE PENELITIAN}

Metode yang digunakan dalam penelitian ini yaitu kualitatif deskriptif. Penelitian kualitatif merupakan suatu metode penelitian untuk mengekplorasi dan memehami makna yang oleh sejumlah individu atau sekelompok orang dianggap berasal dari masalah sosial atau kemanusiaan (Creswell,
2013). Laporan akhir dari penelitian kualitatif mempunyai struktur atau kerangka yang fleksibel. Cara pandang yang digunakan pada penelitian ini yaitu bergaya induktif, berfokus terhadap makna individual, dan menerjemahkan kompleksitas suatu persoalan.Penelitian kualitatif berawal dari lapangan yang didasarkan pada lingkungan yang alami, bukan berdasakan pada teori. Data dan informasi yang telah diperoleh dari lapangan diambil makna dan konsepnya, dipaparkan secara deskriptif analitik dan yang umumnya tanpa menggunakan angka, karena lebih mengutamakan proses yang terjadi dilapangan.

\section{TUJUAN PENELITIAN KUALITATIF}

Pada umumnya penelitian jenis ini tujuannya mencakup informasi tentang fenomena utama yang sedang dieksplorasi dalam suatu penelitian, partisipan penelitian, dan lokasi suatu penelitian. Penelitian kualitatifjuga dapat menyatakan rancangan penelitian yang dipilih.

Dalam dunia pendidikan penelitian kualitatif mempunyai tujuan menggambarkan proses kegiatan pendidikan berdasarkan pada apa yang ada di lapangan sebagai bahan kajian untuk menemukan kekurangan dan kelemahannya sehingga bisa ditentukan upaya untuk memperbaikinya; menganalisis suatu gejala, fakta, dan peristiwa pendidikan yang ada di lapangan; menyusun suatu hipotesis yang berkaitan dengan konsep dan prinsip pendidikan yang didasarkan pada informasi dan data yang terjadi di lapangan.

\section{HASIL DAN PEMBAHASAN}

Berikut adalah hasil deskripsi yang menjawan dari rumusan masalah yang terjabarkan melalui tujuan penelitian sebelumnya.

\section{Hidup Sederhana dan Apa Adanya}

Hidup sederhana tanpa ada rekayasa dari keadaan si tokoh tampak pada apa yang sudah dilakukan oleh tokoh utamanya yaitu Gia.

"yang kadang-kadang bikin kesal adalah tumpah ruahnya loker karena lembaran amplop pink berisi surat cita yang sepetinya habis-habisan disemprot parfum... Saking menyesakkannya, loker kami yang sempit 
sering kali memuntahkan segala isinya begitu pintu dibuka."(11-12, RW)

Dari papran data tersebut tokoh hidup dalam keadaan yang sederhana. Tampak dari loker yang tidak muat untuk menyimpan barang-barang, namun si tokoh tetap memanfaatkannya, sehingga barang yang disimpan kerapkali tumpah karena tidaj cukup.

Hidup apa adanya sesuai dengan keadaan yag ada juga tampak pada deskripsi data tokoh Freya berikut.

"Namun, bukan hanya kemiskinan mendadak yang mendera Freya." (96, RW)

Hidup sesuai dengan keadaan adalah lebih baik daripada hidup penuh gaya tetapi tidak sesuai keadaan sebenarnya. Sikap seperti tokoh Freya membuat masyarakat yang ada disekitarnya lebih dapat menerima sikapnya dengan jalinan komunikasi yang akrab.

\section{Memiliki Rasa Cinta}

Berikutnya yaitu data tentang adanya ungkapan persaan cinta yang dialami oleh tokoh Adrian.

"Adrian sendiri sedang naksir salah scoran teman seangkatan kami, namanya Anggia, teman Freya." (5, RW).

Dalam cerita tersebut Adrian menyukai Gia, wanita yang menjadi teman seangkatannya, memiliki paras yang cantik dengan mata dan pipi yang bundar. Tampak pada kutipan berikut.

"Namanya Anggia Wijaya, cakep, matanya bundar, pipinya juga bundar, enak kalau dicubit dan senyımnya lucu." (8, RW).

Dari paparan data tersebut, sesorang bila menyukai lawan jenisnya hendaknya tetap dilakukan dengan taraf yang wajar, tidak menggebu-gebu atau berlebihan. Laki-laki menyukai apa yang dia lihat secara fisik dari seorang perempuan.

\section{Tidak Memaksakan Kehendak}

Memaksakan kehendak adalah hal yang berakibat tidak baik terhadap orang lain, karena setiap orang memiliki keinginan dan kemampuan yang berbeda-beda. Hal tersebut tampak pada kutipan data berikut.

" Gita anak kelas I-1, nggak suka pelajaran yang ribet-ribet itungannya, paling suka kelas olahraga dan seni rupa karena ia senang menggambar." (8, RW)

Gita lebih menyukai melukis daripada pelajaran matematika, dan itu boleh-boleh saja asalkan dapat dilakukan dengan baik sesuai dengan kemampuannya. Seorang guru tidak dapat mengklasifikasikan pelajaran tertentu dengan tingkat kualitas yang ia tentukan. Karena masing-masing siswa dapat mengembangkan diri sesuai dengan potensinya.

Tokoh Freya memiliki kekurangan dalam bidang olahraga, dan hal tersebut hendaknya berlalu secara alamiah tanpa adanya paksaan agar dia mau menyukai bidang olah raga, tampak pada kutipan berikut.

"Pelajaran olahrahga adalah salah satu kelemahan terbesarku. Aku tidak pernah mampu memegang bola dengan benar, apalagi mencetak skor." (71, RW)

\section{Mudah Bergaul}

Dalam novelRemember. When "Ketika Kau dan Aku Jatuh Cinta" (kajian mimetik) karya Winna Efendi ini juga menggambarkan karakter tokoh yang mudah bergaul, sehingga banyak orang mengaguminya, salah satunya adalah Adrian. Tampak pada kutipan berikut.

"Cewek berambut panjang dan bertubuh mungil kayak dia di sekolah in banyak, tetapi nggak tahu kenapa gue suka aja ngeliat Gia. Orangnya supel banget, jadi enak diajak ngobrol tentang apa saja. Kalau diledek, selalu bisa ngeledek balik. Bersama doa, rasanya sangat menyenangkan.," $(9, \mathrm{RW})$.

Karakter yang digambarkan melalui tokoh Gia, adalah karakter mudah bergaul dalam masyarakat. Dan dampaknya adalah banyak orang yang merasa senang. Hal tersebutjuga hendaknya dapat dilakukan oleh msyarakat, khususnya mahasiswa, sehingga dia dapat diterima dengan baik dalam masyarakat. Terutama dalam dunia kerja kelak.

Dalam kutipan data tersebut, tokoh Gia memiliki perbedaan dengan perempuan lainnya 
saat itu. Dia memiliki gaya yang supel dan menyenangkan. Terutama sikapnya saat berada dalam mobil Adrian, dia menghirup aromatherapi dengan sikap polosnya.

\section{Cerdas}

Karakter tokoh yang tertanam berikutnya yaitu adanya tingkat kecerdasan yang tinggi oleh tokoh Freya, Hal tersebut menggambarkan bahwa penampilan fisik seseorang adala bukan hal yang utama, melainkan ada sisi lain yang lebih penting dan abadi yaitu kecantikan intelensi yang tampak dari sikap tokoh dalam menyelesaikan koflikkonflik dan juga persaingan dalam pemerolehan nilai di dalam kelas. Hal tersebut tampak pada kutipan berikut.

"Sadt itu, namaku dan Freya disebut. Seperti biasa, nilaiku hampir sempurna, dengan Freya satu poin dibawahku." $(4, \mathrm{RW})$

Dari data tersebut dicerikan bahwa tokuh Moses menceritakan bahwa Freya adalah sesosok perempuan yang memiliki kemampuan setara dengannya, terutama dalam bidang matapelajaran ilmu sosial (melukis).

\section{Gemar Membantu Orangtua}

Berikut ini adalah paparan data tentang karakter tokohyang gemar embantu ayahnya dalam pekerjaan. Dan hal tersebut adalah karakter yang mulia dan harus dicontoh oleh para pembacanya.

"Sayangnya hari ini Freya harus pulang lebih cepat untuk membantu ayahnya di toko." $(14, \mathrm{RW})$

Tokoh Freya memiliki banyak kelebihan yang dapat ditiru oleh pembaca, terutama sikapnya yang lebih mengutamakan membantu orang tua daripada aktivitas lain yang sedang ia lakukan.

\section{Hidup Sehat}

Gaya hidup schat sangatlah penting dalam kehidupan. Rajin olah raga, tidak merokok, makan makanan yang sehat dan halal, adalah beberapa bentuk konkret dalam mewrujudkan hidup sehat. Gaya hidup sehat dapat dilakukan oleh semua lapisan masyarakat, bukan hanya keluarga dokter saja. Sedangkan dalam nove tersebut, hidup sehat sudah menjadi budaya pada keluarga tokoh Freya, karena semua anggota keluarganya adalah seorang dokter. Tampak pada kutipan data berikut.

"Ayah adalah dokter kandungan dirumah sakit ternama di Jakarta, sedangkan ibuku membuka praktik di rumah sebagai dokter umum. Kakak perempuanku juga masuk jurusan kedokteran." (135, RW)

\section{Mudah Memaafkan Kesalahan Orang Lain}

Karakter berikutnya yaitu adanya perasaan yang mudah memaafkan kesalahan orang lain, walau itu terkadang sulit. Seperti yang digambarkan pada sosok tokoh Moses berikut.

"Terus terang, aku bukan tipe orang yang mudah memaafkan. Aku tidak ingin mendendam, tapi tidak bisa begitu saja melupakan segalanya yang terjadi." (201, RW)

Moses adalah tokoh yang digambarkan dengan karakter yang pemarah, emosinya gampang meluap, tapi dia juga memiliki sikap mudah memaafkan orang lain, walau itu berat menurutnya, tetapi dia terus berusaha agar tidak menyimpan dendam pada orang lain, sikap seperti tokoh Moses ini juga perlu ditanamkan pada pribadi masyarakat terutama mahasiswa yang merupakan sosok peralihan secara psikologis, dari remaja menuju dewasa, sehingga banyak konflik yang seringterjadi, baik konflik yang terjadi dalam dirinya maupun konflik yang terbentur dengan orang sekitarnya.

\section{Kesimpulan}

Novel populer memiliki beragam kelebihan yang dapat menginspirasi pembacanya. Novel populer tidak sekedar menghibur pembacanya dengan cerita yang penuh iajinasi belaka, tetapi juga mendidik bagaimana seharusnya mereka bersikap yang baik di dalam hidup bermasyarakat. Dengan gaya bahasa yang sederhana, lugas, dan cermat, mampu menanamkan perilaku karakter yang baik terutama bagi kalangan remaja.

Hasil temuan analisis dengan menggunakan teori mimesis dalam penelitian ini yaitu. 1) hidup sederhana dan apa adanya, 2) memiliki rasa cinta, 3)tidak memaksakan kehendak, 4) mudah bergaul, 5) cerdas, 6) gemar membantu 
orangtua, 7) hidup sehat, 8) mudah memaafkan kesalahan orang lain.

Dari delapan hasil temuan tersebut dapat digunakan sebagai amanat cerita yang harus diterapkan dalam kehidupan bermasyarakat sebagai bekal soft skill mercka. Dengan begitu mahasiswa tidak hanya membaca begitu saja cerita populer yang mereka sukai, tetapi juga dapat mengambiil sisi baik dan mengabaikan hal-hal yang tidak patut untuk dilakukan.

\section{Daftar Referensi}

Ahmadi, dkk. 2002. Psikologi sosial. Jakarta: Rineka Citra.
Endraswara, Suwardi. 2013. Metodologi Penelitian Sastra. Yogyakarta: CAPS.

Kresna. 1990. Teuri dan Praktik. Bandung: Refika Aditama.

Suharianto. 1982. Dasar-dasar Teori Sastra. Surakarta: Widya Putra.

Winna efendi.2016. Remember When "Ketika kau dan aku Jatuh Cinta". Jakarta: Gagas Media. 